\title{
Crustal and mantle structure of the Sea of Okhotsk, Pacific Northwest: A review
}

\author{
Geophysical Center of the Russian Academy of Sciences, 119296 Moscow, Molodezhnaya, 3, Russia. E-mail: rodnikov@wdcb.ru
}

The deep structure of the Sea of Okhotsk under seismically dangerous regions is studied. The main feature of the deep structure in the region is the occurrence of an asthenospheric layer in the upper mantle. Asthenospheric diapirs can effectively rise through the crust, causing destruction of the lithosphere, formation of deep basins, faults and rifts accompanied by shallow-focus earthquakes, and eruptions of volcanoes. The vast majority of earthquakes are confined to the Kuril Island Arc, where the Pacific Plate is subducted under the continent. The seismicity in the region is a result of active tectonics in the subduction zone. This zone is traced to a depth of $700 \mathrm{~km}$. In the west, the Okhotsk Sea Region is bounded by the deep faults extending along Sakhalin, where earthquakes are localized in the crust. The ancient subduction zone under Sakhalin is established. In the late Cretaceous to Paleogene the subduction of the Okhotsk Sea Plate under Sakhalin ceased. The reactivation of this ancient subduction zone may currently be in response to the strong earthquakes in Sakhalin.

\section{Introduction}

The main objective of the review is to give better insight into the role of the deep structure of the seismically dangerous regions relating to continental margins. In fact, approximately one-third of the human population lives within the continental margins, meaning they live in a risk zone. The Okhotsk Sea Region on continental margins is characterized with high seismicity, volcanic eruptions and other natural cataclysms. We constructed the geodynamic models for the Sea of Okhotsk to study a deep structure of the crust and upper mantle in such zones. The Okhotsk Sea Region is a large lithospheric plate of the transition zone from the Eurasian continent to the Pacific. The region is located in the contact zone of three lithospheric plates: Eurasian, North American and the Pacific (Fig.1).

\section{Seismicity of the Okhotsk Sea Plate}

The location of the Okhotsk Sea Plate in the contact zone of three lithospheric plates (Eurasian, North American and Pacific) is the cause of a high seismicity on its boundaries (Fig.2).
The highest seismic activity is observed along the Kuril Island Arc. Here the Pacific Plate is moving towards and being subducted under the continent, forming a seismic zone traced to a depth of 700 $\mathrm{km}$. The seismicity is a result of the active subduction zone tectonics in the region. In the west, the Okhotsk Sea Plate is bounded by deep faults extending along Sakhalin. The deep faults correspond mostly to the system of right-lateral strike-slip faults and thrusts. There the earthquakes for the major part are localized in the crust (Zlobin, 2005). Shallow-focus earthquakes are connected with rift structures of a Kuril Basin and Tatar Strait Trough (Rodnikov et al., 2005).

\section{Okhotsk Sea Geotraverse}

The Okhotsk Sea Geotraverse crosses Sikhote Alin, Sakhalin, the Kuril Basin, Kuril Island Arc and Pacific (Fig. 3). The crust is constructed according to data from Galperin and Kosminskaya (1964), Zverev and Tulina (1971), Rodkin and Rodnikov (1996), and Piip and Rodnikov (2004), the upper mantle is constructed from Structure and Dynamics of the Lithosphere and Asthenosphere of the Okhotsk

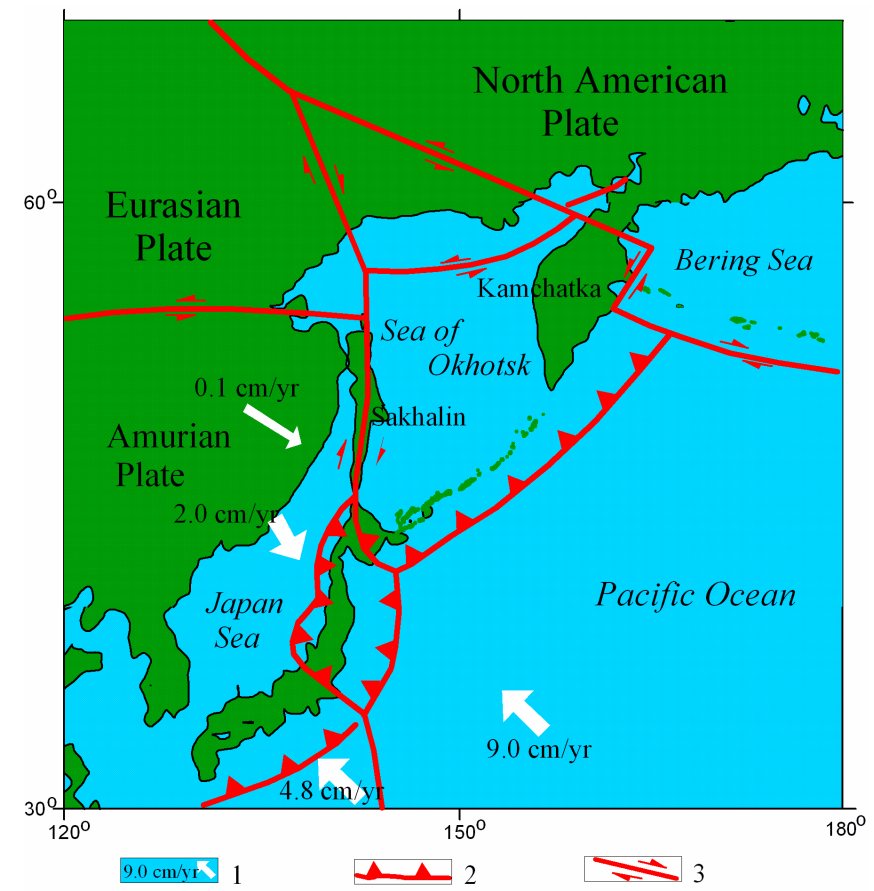

Figure 1. Tectonic map of the Okhotsk Sea Region.1-velocity of plate movement from GPS data; 2-subduction zones; 3-faults. Arrows show plate movement direction. Map is adopted from Kiratzi and Papazachos (1996), Maruyama et al. (1997), Cruise Reports (2000), and Rodnikov et al. (2001). 


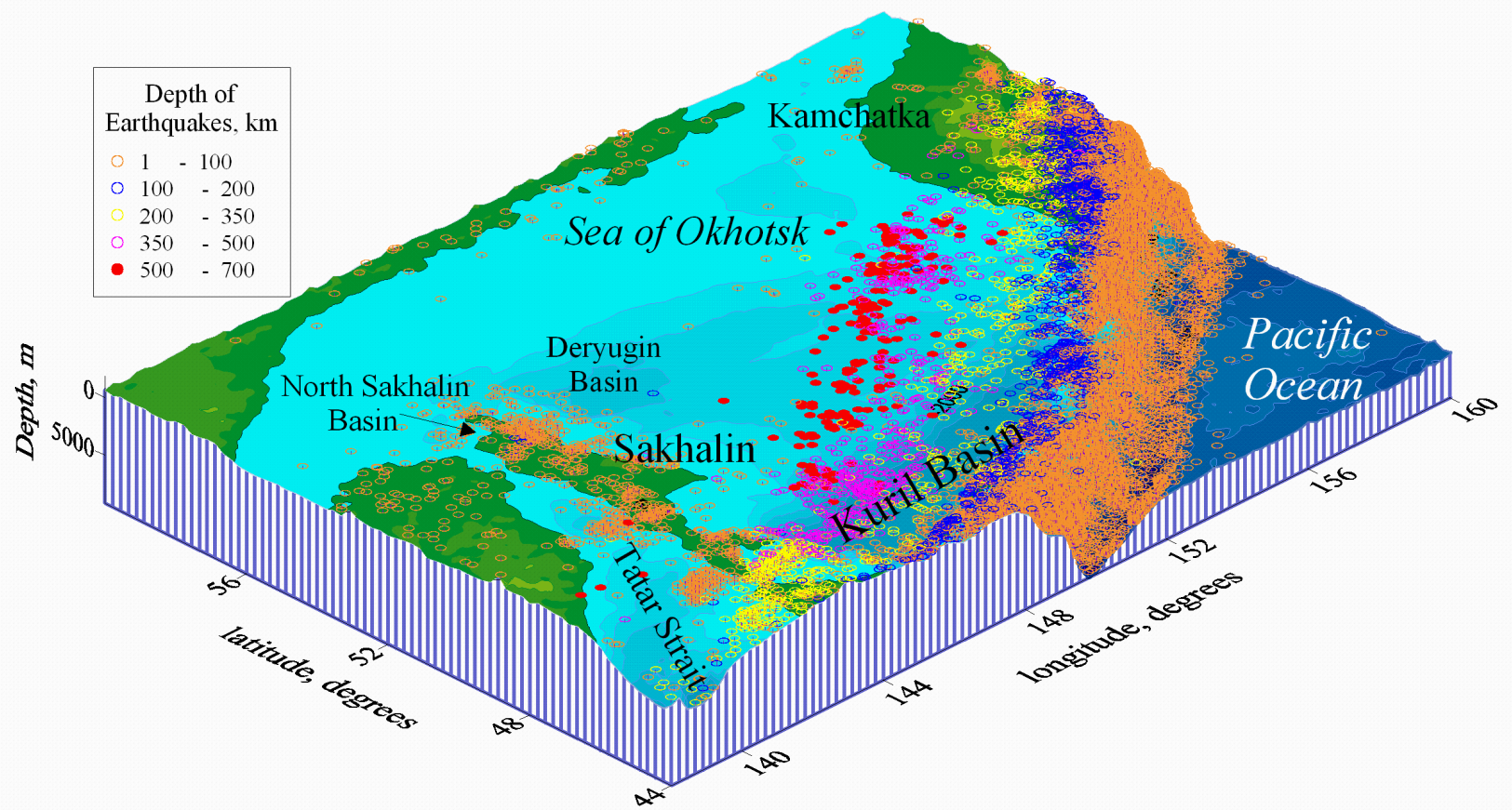

Figure 2. Spatial distribution of earthquakes in the Okhotsk Sea Region for1904-2012, according to Earthquake Catalogs at the USGS National Earthquake Information Center.

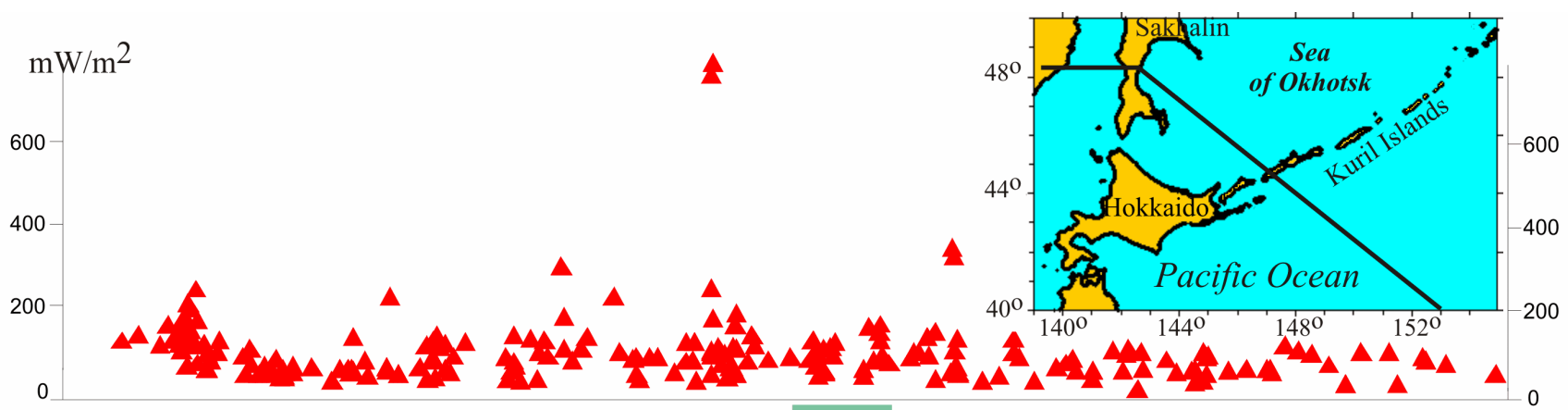

Sikhote Alin Sakhalin FeS Kuril Arc

Pacific Ocean

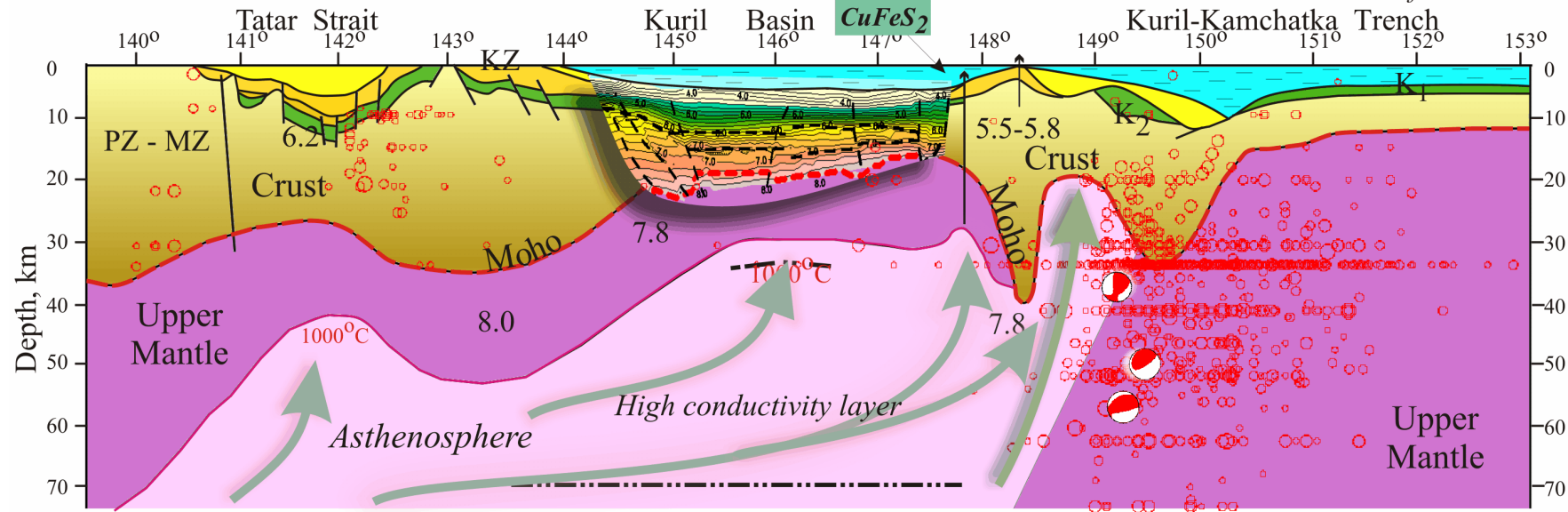

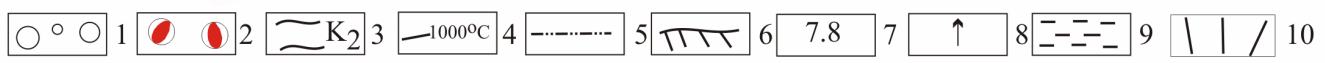

Figure 3. Geotraverse of the Okhotsk Sea Region. At the right top the geotraverse position is shown. Below the distribution of heat flow measurements is shown along the profile. 1 - location of earthquake hypocenters; 2 -focal mechanism; 3 - geological layers; 4 - isotherm; 5 - boundaries of high conductivity layer; 6-Moho discontinuity; 7 - seismic velocities, $\mathrm{km} / \mathrm{s} ; 8$ - volcanoes; 9- water;10-faults. 
Sea Region (Structure, 1996), and Rodnikov et al. (2001), and a heat flow is constructed from Smirnov (1980), Pollack et al. (1991), and Structure (1996). The thickness of the crust along the geotraverse varies from 35-40 km under Sakhalin and the Kuril Islands to 8-10 km under the Kuril Basin (Structure, 1996; Rodnikov et al., 2005; Piip and Rodnikov, 2004). In the Cenozoic, the large part of the sedimentary basins was formed.

The asthenosphere in the upper mantle was essentially established according to the geothermal data (Smirnov, 1980; Smirnov and Sugrobov, 1980; Tuessov and Epanishnikov, 1996). The upper surface of the asthenosphere is on the $1000-1200{ }^{\circ} \mathrm{C}$ isotherms that indicate partial melting conditions (Smirnov and Sugrobov, 1980). The structure of the crust and upper mantle, coefficients of heat conductivity of rocks, and the analysis of thermal model of spreading were used to calculate the deep temperature values of heat flow. The depth, where there is a partial melting in the upper mantle, is taken as an asthenosphere surface. The asthenosphere surface in the Sea of Okhotsk is limited by the isotherm of 1000 to $1200^{\circ} \mathrm{C}$ (Rodnikov et al., 2008). Similar calculations of deep temperatures were carried out for other marginal seas of the western part of the Pacific Ocean (Smirnov et al., 1991). The asthenosphere in the Okhotsk Sea Region is confirmed by seismic, magnetotelluric and geological data. The asthenosphere is characterized by the lower values of seismic wave velocity (Galperin and Kosminskaya, 1964; Snegovskoi, 1974; Structure, 1996). Magnetotelluric sounding allocates conducting layers (Lyapishev et al. 1987), where partial melting takes place in the upper mantle. In an asthenosphere the magmatic centers are located. The crust over of the asthenospheric diapirs is usually thin, and rift structures are widespread. Magma eruptions, generally basalts (tholeiites), often occur along rifts (Filatova and Rodnikov, 2006).

The Sikhote Alin Region is the continental margin of the Asian continent. The results of magnetotelluric sounding in Sikhote Alin showed that the asthenosphere is located in the upper mantle at a depth of $120 \mathrm{~km}$ (Structure, 1996). Magmatic activity continued from the Cretaceous to the Early Quaternary. The Paleogene - Quaternary basalt eruptions consist of tholeiites, subalkaline basalts and olivine basalts. Tholeiites are close to basalts of MORB type and apparently related to magmatic sources in the asthenosphere (Structure, 1996).

The Tatar Strait is a large graben composed of a thick layer (up to 8 to10 km) of the Mesozoic to Cenozoic sedimentary formations. The basement of the strait is composed of the Triassic to Early Cretaceous terrigenous sandy-clayey and volcanogenic-siliceous sediments with P-wave seismic velocities up to $6.0 \mathrm{~km} / \mathrm{s}$. The Moho surface lies at a depth of about 25 to $30 \mathrm{~km}$. Seismic velocities along the Moho are 7.7 to $7.8 \mathrm{~km} / \mathrm{s}$ (Structure, 1996). Probably, the formation of the rift structure in the Tatar Strait is associated with the upwelling of the asthenosphere. There are three stages of magmatic activity in the Tatar Basin: The Eocene to Oligocene basalts, lower to middle Miocene tholeiites and middle Miocene to Pliocene basalts (Filatova and Rodnikov, 2006).

The Island of Sakhalin is separated from the Asian continent by the Cenozoic rift of Tatar Strait. This island is composed of Paleozoic, Mesozoic and Cenozoic rocks. The thickness of the crust provides about 30 to $35 \mathrm{~km}$. Seismic wave velocities vary from 7.8 to $8.3 \mathrm{~km} /$ $\mathrm{s}$ in Moho (Structure, 1996). Major part of earthquakes is localized in the crust. In Eastern Sakhalin an ancient (Upper Cretaceous to Paleogene) subduction zone is distinguished (Grannik, 1999; Rodnikov et al., 2002; Rodnikov et al., 2013). On the surface it is manifested by an ophiolite complex, which separates the North Sakhalin Basin from Deryugin Basin of the Sea of Okhotsk. This complex is represented by harzburgite, dunite, wehrlite, rodingite, gabbro and amphibolite forming ophiolite suites (Rozhdestvenskiy, 1988). It is supposed that 100 million years ago, the oceanic lithosphere of the Sea of Okhotsk subducted under Sakhalin, the eastern part of which was an andesite island arc. In western Sakhalin, behind andesite island arc, there was a back-arc basin where sandy to clayey deposits accumulated in the Late Cretaceous to Paleogene, which subsequently formed the basement of the Cenozoic North Sakhalin oil and gas basin. Approximately 20 to 15 million years ago subduction of the lithosphere of the Sea of Okhotsk apparently ceased. It is established that the Deryugin Basin was formed at the place of an ancient deep trench, and the North Sakhalin Basin is located above the ancient (Late Cretaceous to Paleogene) subduction zone. The position of ancient subduction zone under Sakhalin is a cause of strong earthquakes here. Therefore, this region is one of the seismically active places in Russia (Rodnikov et al., 2013).

The Kuril Basin is a back-arc basin. The thickness of the sediments with the age from Oligocene to Pliocene-Quaternary is near $4000 \mathrm{~m}$. The thickness of the crust attains 8 to $10 \mathrm{~km}$. The depth of Moho in Kuril Basin is at approximately $12-15 \mathrm{~km}$. The seismic velocities on the Moho-boundary are 7.4 to $7.6 \mathrm{~km} / \mathrm{s}$ (Piip and Rodnikov, 2004). In the central part of the Kuril Basin, a rift structure, probably of a spreading structure, is located. The basin is characterized by a high heat flow. The asthenosphere in the mantle appears beneath the Kuril Basin at a depth of $25 \mathrm{~km}$ (Structure, 1996). The electromagnetic research was conducted in the Kuril Basin, and in a depth of $30 \mathrm{~km}$ in the upper mantle a high conductivity layer was identified (Lyapishev et al., 1987). The nature of the layer is associated with partial melting. There are three stages of magmatic activity in the Kuril Basin; the early to middle Miocene, middle to late Miocene and Pliocene times (Filatova and Rodnikov, 2006).

Further, the geotraverse crosses the Kuril Island Arc consisting of two island arcs and a trough between them. The trough is 45 to $60 \mathrm{~km}$ wide and filled with Neogene and Quaternary tuffaceous and sedimentary deposits. The thickness of sediments in the axial zone reaches more than $3 \mathrm{~km}$. The crustal thickness under the trough is as small as $20 \mathrm{~km}$. The asthenosphere in the upper mantle is established at a depth of $20 \mathrm{~km}$, causing the split of the lithosphere, rift structures formation, basalt magma eruptions, and hydrothermal activity (Structure, 1996).

\section{Geodynamic model of the deep structure in the Okhotsk Sea region}

The asthenosphere is located in the upper mantle of the Sea of Okhotsk at a depth of 50-70 km and beneath the Northwest Pacific Basin at a depth of approximately $100 \mathrm{~km}$ (Fig. 4). The formation of the asthenosphere within the Okhotsk Sea Plate is associated with a subduction zone over which it is located (Zhao et al., 2010). From the asthenosphere the diapirs go up to a depth of 25 to $30 \mathrm{~km}$ under the sedimentary trough of the Tatar Strait, Deryugin Basin and Kuril Basin, causing an active tectonics, which manifest themselves in volcanic, seismic and hydrothermal activities (Rodnikov et al., 2002). Beneath the North Sakhalin sedimentary basin, which contains almost all the Sakhalin oil and gas fields, the asthenosphere is located at a depth of approximately $70 \mathrm{~km}$ (Structure, 1996). 


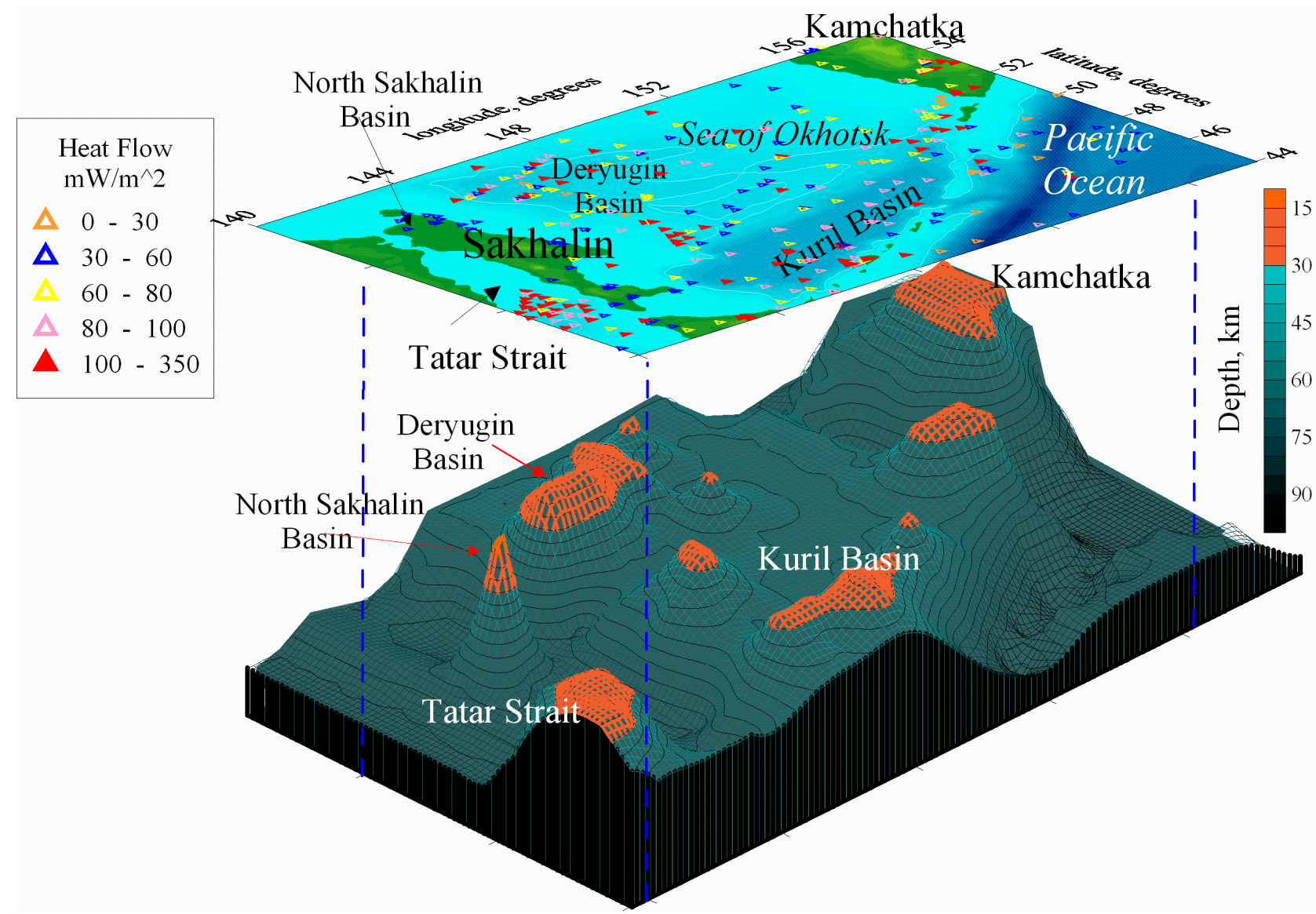

Figure 4. Geodynamic model of the deep structure of the Okhotsk Sea Region. Above - the heat flow measurements in $\mathrm{mW} / \mathrm{m}^{2}$ (Pollack et al., 1991) on the bathymetry chart. The asthenosphere at the upper mantle of the Sea of Okhotsk is located at a depth of 50 to70 km. The diapirs of partial melting go up to the asthenosphere, reaching a depth of 25 to30 km beneath the Tatar Strait Trough, Deryugin Basin and Kuril Basin and causing an active tectonic regime manifested in volcanic, seismic and hydrothermal activity. The area of the red color shows the magma formation.

\section{Conclusions}

A main feature of the deep structure of the Okhotsk Sea Region is related to the occurrence of asthenospheric layer in the upper mantle, processes in which define formation of structures of the crust. When the asthenosphere reaches the crust, fragmented lithosphere, formation of rift structures, eruption of basalts, accompanied by shallow-focus earthquakes, occur.

In the east of the Okhotsk Sea Region the seismicity is associated with the rapid subduction of the Pacific Plate beneath the Eurasian Plate along the offshore Kuril-Kamchatka Trench. In the west under Sakhalin the ancient subduction zone is established. It is probable that the Neftegorsk earthquake May 28, 1995 was a result of reactivation of this ancient subduction (Rodnikov et al., 2013).

The deep basins of the Sea of Okhotsk are located over the asthenospheric diapirs, containing hot mantle fluids. The asthenospheric layer under the Tatar Basin is at a depth of $50 \mathrm{~km}$, under Kuril Basin is at $20 \mathrm{~km}$. There are three stages of magmatic activity in Cenozoic, when basalt magmas erupted.

\section{Acknowledgement}

We would like to thank the Russian Foundation for Basic Research for financial support of our research work (RFBR Project No: 12-0500029-a).

\section{References}

Cruise Reports: Komex V and VI. Kuril Okhotsk Sea Marine Experiment. 2000, Eds.: Biebow N., Ludmann T., Karp B., and Kulinich R, Kiel, pp. 295.

Filatova, N.I., and Rodnikov, A.G., 2006, The Sea of Okhotsk Geotraverse: Tectonomagmatic Evolutin of Cenozoic Extension Structure and Implication for Their Deep Structure: Doklady Earth Sciences, v. 9, pp. 1346-1350.

Galperin, E. I., and Kosminskaya, I. P. (Eds.), 1964, The Crustal Structure of the Transition Region between Asia and the Pacific Ocean, Nauka, Moscow, 308 p.

Grannik, V.M., 1999, Reconstruction of seismic focal zone of East Sakhalin volcanic paleoarc from rare-earth elements distribution: Dokl. Ros. Akad. Nauk, v. 1, pp. 79-83, (in Russian).

Kiratzi, A.A., and Papazachos C.B., 1996, Moment-tensor summation to derive the active crustal deformation in Japan: Bulletin of the Seismological Society of America, v. 86, no. 3, pp. 821-831.

Lyapishev, A. M., P. M. Sychev, and V. Yu. Semenov, 1987.The electric conductivity of the upper mantle in the Kuril Basin, Sea of Okhotsk, Pacific Geology, v. 4, pp. 45-55.

Maruyama S., Isozaki Y., Kimura, G., and Terabayashi M., 1997, Paleo- 
geographic maps of the Japanese Islands: Plate Tectonic Synthesis from $750 \mathrm{Ma}$ to the present: The Island Arc, v. 6, no. 1, pp. 91-120.

NEIC PDE catalog. National Earthquake Information Center, U.S. Geological Survey. http://earthquake.usgs.gov/regional/neic/index.php.

Piip V. B., and Rodnikov A.G., 2004. The Sea of Okhotsk crust from deep seismic sounding data. Russian Journal of Earth Sciences, v. 6, no. 1. pp. $1-14$.

Pollack H.N., Hurter S.J., and Johnson J.R., 1991, The new global heat flow compilation: Department of Geological Sciences, University of Michigan, U.S.A.

Rodkin M.V., and Rodnikov A.G., 1996. Back-arc basin origin and structure. Physics of the Earth Planetary Interiors, v .15, no. 3/4, pp. 235-246.

Rodnikov A.G., Sergeyeva N. A., and Zabarinskaya L. P., 2001, Deep structure of the Eurasia-Pacific transition zone: Russian Journal of Earth Sciences, v. 3 , no. 4 , pp. 293-310.

Rodnikov A.G., Sergeyeva N.A., and Zabarinskaya L.P., 2013. Ancient subduction zone in the Sakhalin Island, Tectonophysics, v. 600, pp. 217-225.

Rodnikov A.G., Sergeyeva N.A., Zabarinskaya. L.P., Filatova N.I., Piip V.B., and Rashidov V.A., 2008, The deep structure of active continental margins of the Far East (Russia): Russian Journal of Earth Sciences, v. 10, no. 4, pp. 1-24.

Rodnikov, A.G., Sergeyeva, N.A., and Zabarinskaya, L. P., 2002, Deep structure of Deryugin basin (the Sea of Okhotsk): The Pacific Geology, v. 4, pp. 3-8.

Rodnikov, A.G., Zabarinskaya, L.P., Piip, V.B., Rashidov, V.A., Sergeyeva, N.A., and Filatova, N.I., 2005. The Okhotsk Sea Geotraverse: Bulletin of Kamchatka Regional Association "Educational-Scientific Center", Earth Sciences, v. 5, pp. 45-58, (in Russian).

Rozhdestvenskiy, V.S., 1988. The geological structure and tectonic development of Schmidt peninsula (Sakhalin Island). The Pacific Geology, v. 3, pp. 62-71 (in Russian).

Smirnov Ya.B., 1980, Termal field of the territory of the USSR. Geological Institute. Moscow, 150 p. (in Russian).

Smirnov, Ya.B., and Sugrobov, V.M., 1980, The Earth heat flow in Kuril Kamchatka and Aleutian provinces: Volcanology and seismology, v. 2, pp. 3-17, (in Russian).

Smirnov Ya.B., Yamato M., Uyeda S., Galushkin Yu.I., Muraviev A.V., Sugrobov V.M., Zhang Ruhui, Wu Qianfan, Li Rucheng, and Zhang Wanxia, 1991, Heat Flow. In: The North China Plain - Philippine Sea Mariana Trench Geotraverse (Eds.: A.G.Rodnikov, N.Isezaki, T.Shiki, S.Uyeda, Liu Guodong), Moscow, Nauka, pp. 97-119 (in Russian).

Snegovskoi, S. S., 1974. Seismic Reflection Survey and the Tectonics of the Southern Okhotsk Sea and the Pacific Margin, Nauka, Novosibirsk, $86 \mathrm{p}$.

Structure and Dynamics of the Lithosphere and Asthenosphere of the Okhotsk Sea Region, 1996. Rodnikov, A.G., Tuezov, I.K., Kharakhinov, V.V., (Eds.), National Geophysical Committee, Moscow, 337 p. (in Russian).

Tuessov I.K., and Epanishnikov V.D., 1996, Lithospheric and asthenospheric structure of the Sea of Okhotsk Region. In: Structure and dynamics of the Lithosphere and asthenosphere of the Okhotsk Sea Region (Eds.: A.G.Rodnikov, I.K.Tuessov, V.V. Charachinov). Moscow, National Geophysical Committee, pp. 112-202 (in Russian).

Zhao D., Pirajno F., and Liu L., 2010, Mantle structure and dynamics under East Russia and adjacent regions: Russian Geology and Geophysics, v. 51, no. 9, pp. 1188-1203.

Zlobin, T.K., 2005, Recurrence and regularities in the dynamics of strong earthquakes seismic processes in Sakhalin: Dokl. Ros. Akad. Nauk, v. 4, pp. 524-527, (in Russian).

Zverev, S. M., and Yu. V. Tulina (Eds.), 1971, The Deep Seismic Sounding of the Earth Crust in the Sakhalin-Hokkaido Sea Zone. Nauka, Moscow, $286 \mathrm{p}$. 